\title{
Nature, Operations and Socio-Economic Features of Street Food Entrepreneurs of Harare, Zimbabwe
}

\author{
TavongaNjaya (Ph.D) \\ Faculty of Commerce and Law, Zimbabwe Open University, Zimbabwe
}

\begin{abstract}
The study sought to investigate the nature,operations and the socio-economic features of street food vendorsin Harare in Zimbabwe. Data collection techniques included in-depth personal interviews, direct observations and documentary reviews. A semi-structured questionnaire was used to collect socio-economic and technical data pertaining to street food vending. The study revealed that street food vending, far from being a hindrance to progress and sustainable development, is in fact the basis of a vibrant street economy which has strong linkages with the formal economy.Street food vendors were observed in most public and private places including industrial and construction sites, hospitals, schools, sporting stadia, bus termini, church buildings, shopping and commercial centres, pavements, open spaces and along streets in the High Density Suburbs. Street food vending survived not merely because it was an important source of employment but because it provided urban dwellers with inexpensive and variedindigenousmeals.This significant contribution was unfortunately ignored by the City of Harare and national police because more often than not street food vending was considered illegal activity and street food vendors were treated as criminals. The study recommended that government should recognise street food industry through legislation and introduction of a code of practice for street food vendors. As a first step towards recognition, street food vendors should constitute themselves into well organised associations which would enable them to develop code of practice for their businesses. Future research should focus on quantifying the consumption of street foods in Harare and their economic benefits.
\end{abstract}

Keywords: Harare; high density suburb; informal economy; street food; street food vendor

\section{Introduction}

Economic downturn, rapid urban population growth, upsurge in HIV and AIDS epidemic, political instability, rising unemployment and lower take-home paydrove someHarare residents into the informal sector as food vendors. However, food legislation, regulation and enforcement have constantly failed to reflect the changing circumstances and incorporate them into town planning to ensure sustainability of street food vending and hence its contribution to sustainable development.

Since the inception of the economic structural adjustment programme in 1990, the phenomena of globalisation, liberalisation and privatisation have led to unprecedented rise in street food vending. It is thus important to explore the nature and operations of street food vending in terms of demographic composition, modalities, initial investment, challenges caused by street food vending and problems faced by the vendors themselves.

\subsection{Review of Related Literature on Street Food Vending}

Street food is defined as ready-to-eat food or drink sold on a street or other public places, such as a market or fair by a hawker or vendor often from a portable stall (Artemis and Bhat, 2000).Dardano, 2003 defines street food as food prepared on the streets and ready-to-eat, or prepared at home and consumed on the streets without further preparation.Citing Tomlins and Johnson (2005), Pikuda and Llelaboye (2009) observed that street foods consisted of staple food served in various forms and in combination with side dishes such as stews, gravies and spices and snacks such as dried meat, fish, roasted yam, fried plantains and cereal-based ready to eat foods. Marketing success of the street food vendors depended exclusively on location and word-ofmouth promotion (Winarno and Allain,1991).

There is increasing recognition that street food vending plays an important socio-economic role in terms of employment potential, providing special income particularly for women and provision of food at affordable costs to mainly the lower income groups in the cities (Chukuezi, 2010).Street-vended foods provided inexpensive nutritious meals (Mosupye and von Holy, 1999) especially the low-income group in the developing countries (Muzaffar et al., 2009).Street food vendors usually take their products to their customers and therefore operate from such places as schools, office centres, market places, railway stations and motor parks, industrial sites and other street corners where they are ready and numerous clienteles (FAO/WHO, 2005 cited in Pikuda and Llelaboye, 2009). According to FAO (2007), over 2.5 billion people eat street food every day. A longitudinal study of food consumption patterns in Bamako showed that street food accounts for 19-27 percent of food 
expenses and provides 134.417kcal per day per person (Ag Bendech et al.2000 cited in WHO, 2006). In Africa, street food vending employed on average 37.8 percent of the labor force and contributed about 38 percent to total gross domestic product(Charmes, 1998). Women predominated in street food business representing 53 percent of the vendors in Senegal (Wirnano and Allain, 1991) and 75 percent of the vendors in Burkina Faso (Barro et al. 2002 cited in WHO, 2006).

Concerns of cleanliness and freshness often discouragedsome people from eating street food. With the increasing pace ofglobalisation and tourism, the safety of street food has become one of the major concerns of public health and a focus for governments and scientists to raise public awareness (Mukhola, 2007; FAO, 2007). An assessment of some street foods widely consumed in Ouagadogou, Burkina Faso showed that vendors did not respect hygienic practices (WHO, 2006). In Accra, Ghana, a study to evaluate the role of street food vendors in the transmission of diarrhoeal pathogens showed that in 35 percent of the vending sites food was exposed to flies while 17.1 percent of the vendors handled food at ground level (Mensah et al. 1991 cited in WHO, 2006). In the United Kingdom, the Food Standards Agency provides comprehensive rule of food safety for the vendors, traders and retailers of the street food sector. In Mumbai, India, the Food Safety Act, 2011 requires hawkers, food vendors including vegetable and fruit vendors to follow basic hygiene rules such as wearing an apron and gloves and using clean utensils and potable water. Other effective ways of enhancing the safety of street foods are through mystery shopping programmes, through training and rewarding programmes to vendors, through regulatory governing and membership management programmes, or through technical testing programs.

Opponents of street food vending component of the informal sector argue that the informal sector is incapable of playing any developmental role and that the people in this sector are destined to remain marginal to the rest of the economy (Sethuraman, 1981; Manning, 1993). Under this trend of thought the businesses in the informal sector are classified as survivalist enterprises that will not drive economic growth in developing countries and in fact will disappear over time as the formation of official firms increase to stimulate growth in the formal sector (Sethuraman, 1981; Ruel et al. 1999). They note that these businesses have owners with limited skill training, little capital investment which oftentimes translates into limited opportunities for growth into a viable business.

The views of opponents of informal sector entrepreneurship are based on misguided assumptions and not empirical data (Tinker, 1997). The advocatesof informal sector economy argue that the scarcity of statistics not only down plays the significance of women's entrepreneurship in the informal sector but poses a problem in quantifying with any precision the economic contribution of these activities to the economy of developing countries, particularly in Africa (Tinker, 1997; Sardier, 2003; Verick, 2006). The omission of informal activities from economic accounting statistics may significantly underestimate gross domestic product and overestimate the share of the population living below the national poverty line. In Zimbabwe, street food vending is a growing urban phenomenon. However, the nature and operations of street food vendors are not properly understood because the trade has no legal status. In this study, the term street vendor includes stationary or static vendors who occupy space on the pavements or other public/private spaces with temporary stalls.

\subsection{Statement of the Problem}

Although street food vendors have occupied the streets of Harare en-masse, their activities and motivations have remained poorly understood. As the economic melt-down worsens as epitomised by company closures on a mass scale, more and more people find themselves depending on street food vending for their livelihoods. Informal businesses in general and street food vendors in particular are commonly considered to be typical informal workers who invariably escape compliance with state regulations of their business enterprises. But, what is the nature of street food vending in Harare? What are the modalities and operations of street food vendors in Harare? What challenges have been brought by street food vending? These were the overarching issues addressed in this study.

\subsection{Study Objectives}

The study's primary aim was to investigate the nature, operations and socio-economic features of street food vendors in Harare.The specific objectives of the study were:

- To establish the socio-economic characteristics of street food vendors.

- To describe the nature of street food vending in Harare.

- To examine the modalities or operations of street food vendors in Harare.

- To identify problems cause by street food vending in Harare.

- To identify problems and impediments faced by street food vendors in Harare.

\subsection{Research Questions}

- What are the socio-economic characteristics of street food vendors?

- What is the nature of street food vending in Harare? 
- What are the modalities or operations of street food vendors in Harare?

- What problems have been caused by street food vending?

- What are the problems and impediments faced by street food vendors in Harare?

\section{Study Methodology And Design}

The study used mixed methods research (Creswell, 2009). Data collection techniques included in-depth personal interviews, direct observations and documentary reviews so as to triangulate the evidence. A semistructured questionnaire based on the study's objectives (Bryman, 2001) was used as the basic tool to collect socio-economic and technical data pertaining to street food vending. Closed-ended questions enabled the researcher to ask standardised questions and to collect uniform data from the selected vendors while open-ended questions were used to explore current situation of street food vending in Harare. The questionnaire was administered by the researcher at the respondents' vending sites where the researcher used that opportunity to start group discussions with vendors present in order to obtain in-depth information.Descriptive statistics such as means and frequencies and thematic analysis were used to present the research's results and findings respectively. The individual static street food vendor was the unit of analysis.

Six high density suburbs of Budiriro, Highfield, Glen Norah, Glen View, Mufakose and Warren Park were selected as the study area on the basis that these are representative of the typical high density informal sector business activities in Harare. Sixty street food vendors were randomly selected in the six high density suburbs. This was done to avoid bias in the selection of the respondents. Within the suburbs, the researcher randomly selected and interviewed ten street food vendors after they had given their consent and had been assured total confidentiality. In-depth interviews were held with officials from the City's Departments of Health, Housing and Community Services and Surveying and some consumers of street foods in order to enrich the study.

\subsection{Description of the Study Area}

Harare is the capital city of Zimbabwe. It has an estimated population of 2.098 million (ZIMSTAT, 2012). Harare was purposively selected because of its diversity in terms of economic activities and the higher growth of street food vending. Harare has 36 suburbs where 15 are high density, 8 are medium density and 12are low density suburbs. There is one informal settlement in Harare called Hopley. Dominant human activities in Harare's high density suburbs include illegal stream bank and unutilised space agriculture and street vending. Fig.2.1 shows a map of Greater Harare and the six study sites of Budiriro, Highfield, Glen Norah, Glen View, Mufakose and Warren Park. All the six high density suburbs are found on the western side of the central business district.

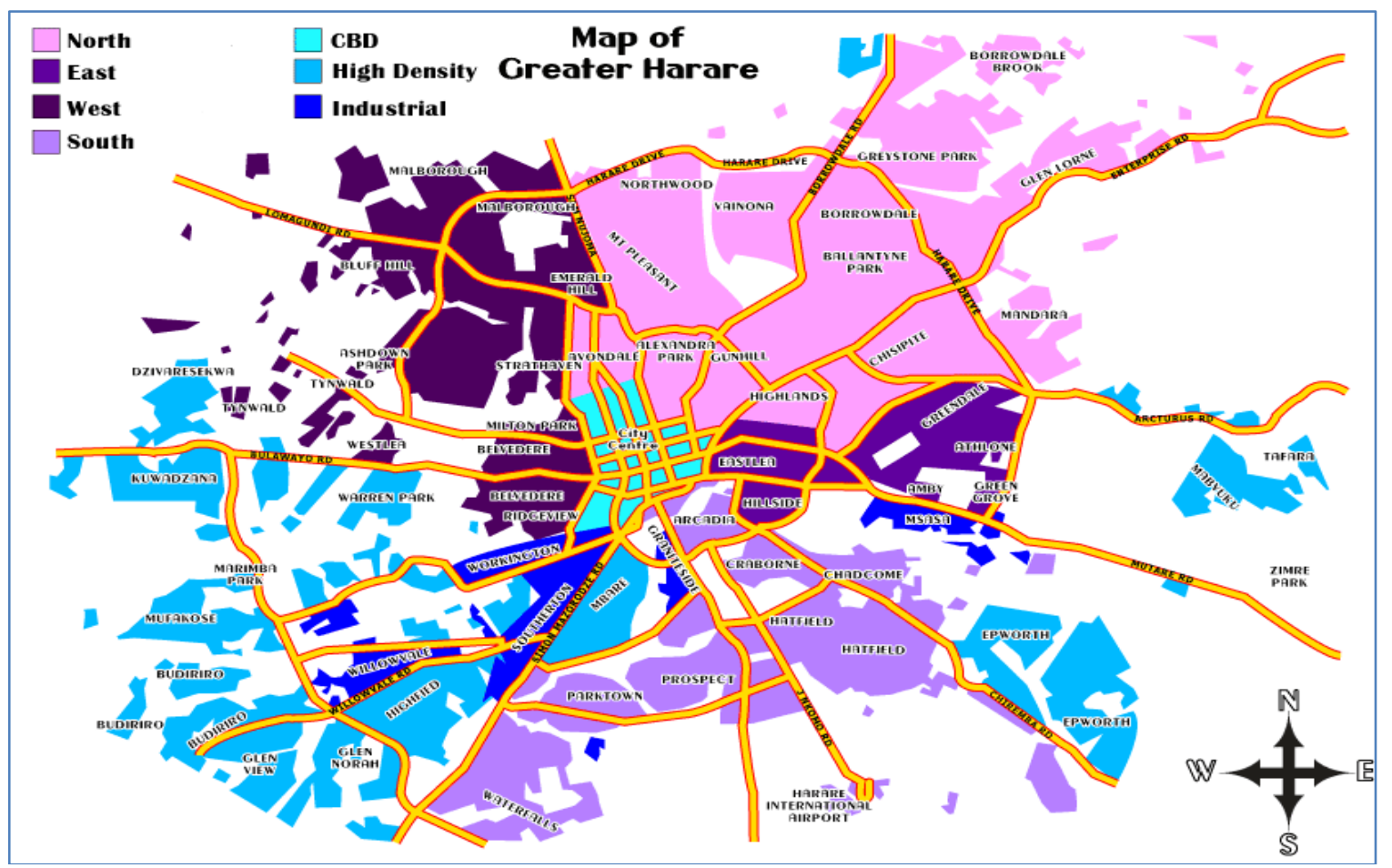

Source: Surveyor General

Figure 1: Map of Greater Harare showing the study sites 


\section{1}

\section{Presentation Of Results And Discussion Of Findings}

Socio-economic Demographic Characteristics of Street Food Vendors

Table 3.1 shows the socio-economic and demographic characteristics of street food vendors in the six high density suburbs. A majority of the street food vendors were from poor backgrounds. Women predominated in street food vending representing 85 percent of the vendors. This was due to a number of socio-economic factors such as failure to secure formal employment due to lower education and skills levels. Also household work such as child care could force some women into street food business. This was because street food business allowed a woman to do other household chores besides vending. The third factor was that street food business required relatively small capital base and hence easier to penetrate by housewives. In-depth interviews revealed that a majority of the females engaged in street food vending in order to supplement their husbands' lower wages. Given the financial burden carried by most female street vendors at household level and limited start-up budgets, the room to expand the business was constrained for the majority of them.

A majority of the food vendors (46.7 percent)were in the 21-30years age group. This is the economically active age group and their participation in street food industry reflected the high unemployment levels in the country. The informal sector and in particular street food vending, because of relatively low capital requirements had become the only source of income for the unemployed. Peak prevalence in education wasOrdinary Level with 55 percent of all those surveyed. Those whofailed to reach Ordinary Level were femaleand cited various reasons which included economic (financial) (73 percent), social (for example, early pregnancies)(16 percent) and inability or unwillingness to continue their education (11 percent).

TABLE 3.1:Demographic characteristics of street food vendors in Harare

\begin{tabular}{|l|l|}
\hline Parameter & Percentage (Frequency, $\mathbf{n}=\mathbf{6 0}$ ) \\
\hline Age (years) & \\
\hline Below 20 & 0 \\
$21-30$ & 46.7 \\
$31-40$ & 31.7 \\
$41-50$ & 13.3 \\
$51-60$ & 5.3 \\
Over 60 & 3.0 \\
\hline Sex & \\
\hline Male & 15 \\
Female & 85 \\
\hline Marital Status & \\
\hline Single & 25 \\
Married & 55 \\
Divorced & 10 \\
Widowed & 10 \\
\hline Educational Qualification & \\
\hline Zimbabwe Junior Certificate & 25 \\
Ordinary Level & 55 \\
Advanced Level & 11.7 \\
Diploma & 5 \\
Degree & 0 \\
Other & 3.3 \\
\hline Type of Housing & \\
\hline Owned & 15 \\
Rented & 75 \\
Other & 10 \\
\hline Alternative source (s) of income & \\
\hline Yes & 10 \\
No & 90 \\
\hline
\end{tabular}

Other ${ }^{*}$ refers to vendors staying with parents or relatives

Table 3.1 also shows that 75 percent of street food vendors lived in rented houses. About 90 percent of the vendors relied solely on street food vending. This showed that street food vending, though illegal had helped to reduce unemployment and enhance livelihoods of some urban households. This showed that Harare residents resorted to street food vending as a coping and survival strategy in the face of high unemployment and lower wages in the formal sector, confirming earlier observations (Kwankye, Anarfi, Tagoe and Castaldo, 2007; Mitullah, 2005; Sethuraman, 1981) that street vending is undertaken as a survival strategy by the urban poor. 


\subsection{Nature and Modalities of Street Food Vending}

Street food vendors were observed in most public and private places including industrial and construction sites, hospitals, schools, sporting stadia, bus termini, church buildings, shopping and commercial centres, pavements, open spaces and along virtually every street of Harare's High Density Suburbs. The major modalities of street food vendors observed in the study area included mobile, stationary, fixed and itinerant vendors. The type of facilities of street food vendors included kiosks, open spaces, wooden or canvas or polythene stalls, hawker's kiosks, push carts, cyclesand vans with food service equipment. The equipment used included baskets, plastic boxes, firewood braziers, gas stoves, braai stands, cooler boxes, plastic buckets and refrigerators while cooking utensils observed included pots and pans (usually black which are suitable for use on fire, spoons, (wooden and metal), plates (metal and plastic), knives, cups (metal and plastic), dishes or bowls (metal and plastic). A majority of the street food vendors operated from open spaces near offices and shops as well as along major roads leading to shopping centres.

The scope of ready to eat food on the street was quite broad. The broad categories of street foods observed in Harare included snacks, main meals and beverages. Table 3.2 shows the types of ready to eat street food while Table 3.3 shows the sources of raw materials used in the preparation of street-vended foods in Harare.

TABLE 3.2: Main categories of ready to eat street food

\begin{tabular}{|l|l|}
\hline Source of Food & Type of Preparation \\
\hline Cattle & $\begin{array}{l}\text { BBQ, cow heels, cow head, jerked beef, hamburgers, stewed, knuckles, beef sausages, intestines, } \\
\text { lungs }\end{array}$ \\
\hline Pig & BBQ, pork ribs, pork sausages, hot dog, trotters, pig head, stewed, pork pies \\
\hline Chicken & BBQ, chicken feet, stewed, gizzards, intestines, liver \\
\hline Fish & BBQ, steamed, stewed \\
\hline Maize & Maize meal (sadza), roasted or steamed mealies \\
\hline Other foods & $\begin{array}{l}\text { Fruits and vegetables, ice cream, sweets, bread, biscuits, fried potato chips, hot dogs, beverages } \\
\text { (fizzy drinks and tea), beer, illicit imported spirits }\end{array}$ \\
\hline
\end{tabular}

TABLE 3.3: Sources of raw materials for street-vended foods

\begin{tabular}{|l|l|}
\hline Food & Source \\
\hline Vegetables & Fellow vendors, established vegetable markets such as Mbare and Machipisa, farmers \\
\hline Meat & Licensed shops, abattoirs \\
\hline Fish & Licensed shops, vendors \\
\hline $\begin{array}{l}\text { Other groceries (e.g. salt, } \\
\text { mealie-meal, rice etc.) }\end{array}$ & Licensed shops, wholesalers \\
\hline
\end{tabular}

What can be noted from Table 3.3 is that street food vending sector provided the urban economy with strong backward and forward economic linkages. For example, street food vendors provided a reliable market to licensed shops, wholesalers, abattoirs and established vegetable markets as well as fellow vendors.This significant contribution, in addition to employment creation, was unfortunately ignored by the government which regarded street food vending in particular and street economy in general, as a hindrance to economic progress and sustainable development. The following sections extend the discussion of modalities of street food vending sector in terms of major consumers, food storage, water sources, waste disposal, sanitary conditions and personal hygiene.

\subsubsection{Major Consumers of Street Food}

The local residents made up 51.1 percent of the consumers of street-vended food in the study area. The growing mega trends for street food could be attributed to preference for locally produced organic foods and widening of flavour concepts in fast food. Street food vendors provided convenient and delicious meals to some citizens who worked for longerhours and others who preferred to eat out than preparing meals at home. With an increasing number of women joining the working population group, the need to cook at home is gradually getting eroded to some extent. Fellow informal workers involved in petty trading (for example flea market traders) and informal artisans including metal workers, carpenters and motor mechanics and panel beaters made up 18.6 percent of street food consumers. Workers from licensed shops and government offices constituted another significant group of consumers of street foods (30.3 percent). These preferred street foods because they were easily accessible, offered a wide variety, were affordable and sometimes had flexible paying options for regular customers. For example, a plate of sadza and beef stew cost $\$ 1$ on the street and $\$ 3$ in a licensed shop. A survey of licensed shops near street food vending sites showed that some of the shops had actually reduced or had completely stopped selling fast food and snacks. The most important thing about street shopping is that one is dealing with a human person where prices are usually negotiated and informal credits could be granted to 
consumers. On the other hand, the treatment in shopping malls is mechanical and the transaction lacks humanity which is always present in street commerce.

\subsubsection{Food Storage}

Raw foods and sometimes cooked food were transported to and from home using public transport or push carts and sometimes own transport for those who owned cars. There were nomodern hot holding facilities at most vending sites visited. Instead, food (maize meal or sadza and meat) was left in pots on firewood braziers or braai stands. A few stalls had refrigeration facilities. In the majority of stalls, cold food was stored at ambient temperature and sometimes in cooler boxes stacked with ice.

\subsubsection{Water Sources}

About 99 percent of the street food vending sites in the study area lacked potable water. Instead, water was conveyed to stalls incontainers making the quantities inadequate for effective washing and disinfecting of the utensils.Most vendors used bowls for washing hands and utensils although there were cases where the waterwas not changed often enough. Soap and drying towels were unavailable at most vending sites visited.Although drying towels were available at Mereki in Warren Park D, these were not changed often enough.

\subsubsection{Waste Disposal}

A small group of vendors had facilities for the storage of refuse in plastic bags or bins. However, sometimes food scraps were indiscriminately and/or accidentally deposited by consumers at the service site. The failure to remove this litter created unsightly conditions and attracted rodents and insects.

\subsubsection{Sanitary Conditions}

Most vending sites in the study area were found to be generally filthy, dusty and smoky. Inconvenient and unhygienic eating places were the major infrastructural problems observed in the study areas. The cooking areas were often situated near rubbish dumps, skip bins or public toilets exposing both the vendors and consumers to food contamination. About 82 percent of the public toilets (most of them within the proximity of the vending sites) were not in working order. The researcher was informed by the vendors that sometimes the skip bins were not emptied on a regular basis.

Some of the street food vendors prepared food items at home and then transported them to thevending sites for sale. However, properstructural requirements, sanitary facilities, waste handling and general hygiene for preparing andhandling food safely at home level are not present (Dardano, 2003) which could result in contamination during food storage and transportation and thus leading to food-borne diseases. A majority of the street food vending sites were not equipped withproper facilities for the storage of hot and cold foods. Where the vendors did not have refrigerators,cold foods were kept in cooler boxes stacked with ice. Because the vending times were sometimesprolonged, the cold temperatures could not be maintained. For vendors who prepared food at home, hot foods were stored in pots or plastic boxes where hot temperatures sometimes could not be maintained due to extended vending periods. However, for vendors with fixed temporary stalls, the majority of them (98.3 percent) used either firewood or waste paper to prepare food. Some this category of vendors provided hot meals and cold foods because they had charcoal stoves and refrigerators. Very few of the street food vendors used gas or electricity for cooking. Gas was mostly used by vendors who sold fried potato chips, sausages and hot dogs.

\subsubsection{Personal Hygiene}

Most vendors were conscious about personal cleanliness. The vendors did not have protective clothing such as chef's hats or head nets and gloves posing a health hazard. In the entire study area, only three percent of the vendors had aprons. However, a majority of the vendors had fairly good personal hygienic practices andhandled food with "clean" hands. The research noted that although the food was prepared in the open, it was immediatelycovered and kept by the fire side in order to retain hot temperature.

\subsection{Sources of capital and operations of street food vending businesses}

Table 3.4 shows that half of the street food vendors had an initial investment of overUS\$40 which mostly came from own savings (90 percent). Investments of over $\$ 40$ were made mainly by women. The interviews showed that most marriedwomenreceived the money to start business from their husbands. Thisshowed that street food vending was undertaken as a copingstrategy to complement husbands' lowwages. This was confirmed by the uses of the income from food vendingbusiness. Most street foodvendors used their income to meet basic household requirements such as paying rent, rates, water andeducation and buying groceries and clothing. 
Informal rotating savings and credit schemes were common among street food vendors. These informal rotating savings and credit schemesprovidedan alternative source of working capital to members of the group.For example, in Glen View, each vendor contributed $\$ 10$ per day to therotating savings scheme-which benefitted one of the vendors on that particular day. The additionalincome was used to buy more raw materials or business equipment.

A majority (95 percent) of street food vendors claimed that they prepared basic books of accountsfor their businesses. This showed that although street food vending was a survival technique, most vendors regarded it as a business enterprise that required effective management. About 60 percent of the street food vendors however indicated that they required training inbusiness management, catering and foodhandling.

TABLE 3.4: Initialincome, books of accounts, registration status andnumber of employees

\begin{tabular}{|l|l|}
\hline Parameter & Percentage (Frequency, $\mathbf{n = 6 0}$ ) \\
\hline Initial Income, US \$ & 0 \\
\hline Below 20 & 20 \\
$21-30$ & 30 \\
$31-40$ & 50 \\
Over 40 & \\
\hline Source of Income & 90 \\
\hline Own Savings & 0 \\
Loan from bank & 0 \\
Loan from relative (s) & 10 \\
Donation & \\
\hline Period operating business (years) & 60 \\
\hline Below 1 & 5 \\
2-3 & 35 \\
Over 3 & \\
\hline Availability of books of accounts for the business & 95 \\
\hline Yes & 5 \\
No & \\
\hline Number of employees & 55 \\
\hline Nil & 15 \\
One & 15 \\
Two & 15 \\
\hline More than two & \\
\hline Business Operating times & 41.7 \\
\hline 6 am-7pm & 58.3 \\
6am-10pm & \\
\hline
\end{tabular}

The majority (55 percent) of the street food vendors were small scale entrepreneurs of owneroperatedbusinesseswho worked alone or with the help of unpaid family labour.Street food enterprises aregenerally small in size; require relatively simple skills, basic facilities and small amounts of capital.Family labour including children was crucial inside and outside the home. From the survey, children helped their parents or guardians in washing dishes and preparing food. From the survey, 45 percent employed between one and eight workers. This showed that although street food vending was not recognised, the industry had helped to reduce unemployment in the City.

\subsection{Formality and Regulation of Street Food Vending}

About98.3 percent of the street food businesses were not registered by the Harare City Council. This was because the City by-lawsdid not allow vending of cooked food. The City issuedhawker's licenses which included a restriction on the type of food sold (vegetables) and the location where they could be sold.The City used the Public Health Act, Chapter15.09 and the Food and Food Standard Act, Chapter 15.04 which unfortunately did not address the salient aspects of street food vending. The Public Health Act has origins in colonialism and was designed to protect established businesses while subjecting small businesses (mostly owned by blacks) to harassment for failure to meet prescribed standards. On the other hand, the Food and Foods Standards Act was designed with stringent conditions for registration and excluded blacks. Most vending operations took place at undesignated sites except for Mereki in Warren Park D. Initially Mereki was undesignated and was only designated as an after thought.

The street food industry is spread over different locations and is not systematically coordinated which makes the Harare City Council to regard such clusters of street food vendors as impediments to urbanplanning and hazards to public health. Because streetfood vending was an unrecognised industry had often justified harassment of the vendors by thelocal authorities. The majority of unlicensedvendorscomplained about raids and confiscations of their foods and cooking utensils by both the national andmunicipal police. The fine charged is US\$20.However, 
police raids often led to riotoussituations and loss of property. On 10January2012, street vendors shattered the windowsof apolice post in First Street, Harare after the police confiscated their wares. But why would the City ignore a sector where a majority of its citizens obtained their livelihoods? Themajorproblem seemed to bethe City's masterplan(designed during the colonial period) which didnot allocate space to vendors as townplanners blindlyreplicated the westernconcept of marketing which ignored theZimbabwean traditions. Hart (1973) concurred and argued that government planning and the effective application of economic theory in the informal economy had been impeded by a wholesale transfer of western categories to the economic and social structures of African cities. The moderndevelopment approach isoriented towardsshopping malls which are not built on theconcept of a public that cannot afford tolive expensive lifestyles. The City by-laws should be adapted to the changing circumstances to accommodate street economic activities but at the same time retaining the ability to regulate the safety of street-vended foods.

\subsection{Problems caused by Street Food Vending}

The following were identified by citizens and the City of Harare as the major problems caused by street food vending;

- congestion of both humans and traffic due to spill-over business of street food vendors

- $\quad$ obstruction of fellow citizens doing their business

- unsafe foods

- vendors' business refuse (garbage) cause unsightly urban vista

- hazardous environment caused by the absence of water and sanitation at some vending sites

- $\quad$ street food vending obstructs the maintenance of law and order in the City

\subsection{Problems faced by Street Food Vendors}

The following were listed by street food vendors as the major problems they faced in their business;

- $\quad$ raids and confiscations of their merchandise and cooking utensils by both the national and municipal police

- competition fromnew entrants

- $\quad$ erraticsupply of raw materials

- lack of business management skills (especially vending skills)

- lack of proper food handlingtechniques

- hostile customers (especially men), some of whom seldom refuse to pay

- harassment andexploitation by nationalpolice and municipal authorities

- poor social protection

- constant fatigue caused by spending long hours in the sun

- lack of public utilities (roads, electricity, toilets,potable water and waste disposal)

- lack of organisational strength and voice

- lack of dignity and/or right to work

- $\quad$ insecurity of mobile women vendors

\section{Conclusion And Recommendations}

The study showed that street food vending is a vital community development tool as it plays very important socio-economic role in Harare.Street food vending, far from being a hindrance to progress and sustainable development, is in fact the basis of an alternative street economy which is people friendly and with the necessary institutional and infrastructural support can be both environmentally-sensitive and energy conscious. Street foods are an important but an unexplored facet of Zimbabwe's street economy, food and nutrition. Although street food vending is illegal and unrecognised, it significantly helped to reduce unemployment, increased incomes of vendors, provided strong economic linkages in the economy and provided urban dwellers with inexpensive, varied and nutritious indigenous meals. However, quality, hygiene and safety problems, encroachment on roadsides and pavements, possible contribution to the deterioration of law and order and disturbances in the lives of other citizens were the major concerns to the City of Harare. This has often justified harassment of street food vendors by the local authority. In order not to overshadow the significant role played by street food vending, there is need to regulate/control street food to ensure safety and thus reduce the occurrence of food borne diseases.Future research should try to quantify the consumption of street foods and their economic benefits in Zimbabwe.

The business of street food vending needs to be addressed carefully in order to derive maximum benefits for the entire economy. Generally, there is need to integrate the street economy into the mainstream economy in a way that would ensure sustainability of the former and long-term economic growth and sustainable development of the country. With this in mind and recognising the fact that street foods have become a permanent feature of the Zimbabwean society, the researcher made the following recommendations; 
- TheCity of Harare should recognise street food industry through legislation and introduction of a code of practice for street food vendors. This would require an analysis of the legal obstacles and extra legal practices that hinder smooth formalisation of informal traders. Formalisation through legislation of vending on the streets will make it easier for the vendors to thrive while working within the existing regulatory framework. The regulations would need to be designed equitably and vendor license fees charged should be sustainable so that vendors are able to stay within the regulatory framework. In addition, the regulations should integrate the interests and ideas of street food vendors and relevant policy makers in order to develop a sustainable model of street food vending that would secure and strengthen the livelihoods of the vendors.

- In tandem with formalisation, action-oriented research should focus on compiling data to identify and profile the nature of street food vendors (mobile, semi-mobile, static and footpath vendors) and establish the number of people who depend on street food vending for their livelihoods.

- As a first step towards recognition, street food vendors should constitute themselves into well organised associations which would enable them to develop code of practice for their businesses or constitute a forum for interaction with the City of Harare.

- Non-governmental organisations and vendors should start regular consultations to coordinate advocacy programmes with a view to recognition and formalisation of street food vending.

- In the interim, toilets should be rehabilitated and water reconnected and sanitary facilities used by street food vendors should be provided.

- The City of Harare should construct decent shelters which can be rented by street food vendors. Alternatively, the city council can construct a prototype model for food vending stall or kiosk which will be made available for sale possibly through microfinance. In addition, the city council should provide essential public utilities such as potable water, garbage collection, electricity and public toilets. This will entail creating space for vending for old suburbs and including vending space for new suburbs. In Hong Kong, China, Singapore and Malaysia, local authorities construct hawker centres which are open-air complexes that house many stalls selling a variety of inexpensive food. These complexes were built partly to address the problem of unhygienic food preparation by unlicensed street vendors. Street food vending has tremendous benefits to customers. The advantage of open air vending sites is that they are often popular with tourists who want to taste indigenous foods-which are not served in hotels, restaurants and fast foods outlets. In Latin America, street food purchases account for up to 30 percent of urban household spending whilst in Bangkok, twenty thousand street food vendors provide city residents with an estimated 40 percent of their overall energy intake (FAO, 2007).

- Non-governmental organisations and Harare City Council should design on the job training seminars for street food vendors on issues of food handling, marketing, credit, business development and hygiene in the productionof safe foods.

\section{References}

[1]. Artemis, P. S. and Bhat, R.V. (2000).Street Foods.Basel: Karger Publishers

[2]. Azuma, Y. and Grossman, H.I. (2008).“A Theory of the Informal Sector”.Journal of Economics and Politics, Wiley Blackwell, Vol.20, No.1, pp62-79

[3]. Bryman, A. E. (2001). Social Research Methods. Oxford: Oxford University Press.

[4]. Chukuezi, C.O. (2010). "Entrepreneurs of the Streets: Socio-Economic Features of Street Food Vending in Owerri, Nigeria". European Journal of Social Sciences, Vol. 14, No. 2, pp183-188

[5]. Creswell, J. W. (2009). Research Design: Qualitative, Quantitative and Mixed Method Approaches.(3 ${ }^{\text {rd }}$ ed.). Thousand Oaks, CA: Sage Publications Ltd.

[6]. Dardano, C. (2003).Carribbean regional working group on street food vendors, Report ofFAO, PAHO and BNSI. http://ftp.fao.org/es/esn/food/carribean report.pdf, (Accessed 25 August 2011)

[7]. $\quad$ FAO (Food and Agriculture Organisation) (2007).School kids and street food. Spotlight Magazine, Agriculture and Consumer Protection Department,United Nations.http://www.fao.org/AG/magazine/0702sp1.htm, (Accessed 25 August 2011)

[8]. Hart, K. (1973). Informal Income Opportunities and Urban Employment in Ghana. The Journal ofModern African Studies, Vol.11, No.1, pp61-89. DOI-http://dx.doi.org/10.1017/S0022278x00008089

[9]. Kwankye, S., Anarfi, J., Tagoe, C., and Castaldo, A. (2007). Coping strategies of independent child migrants from northern Ghana to southern cities. Development Research Centre on Migration, Globalisation and Poverty, University of Sussex Working Paper T-23

[10]. Manning, C. (1993). 'International experiences of informal sector activity and the lessons for South Africa'.Transformation 22. http://www.transformation.ukzn.ac.za/archive/tran022/tran022006.pdf(Accessed on 24 October 2011)

[11]. Mitullah, W.V. (2005). Street vending African cities: A synthesis of empirical findings from Kenya,Cote d'Ivoire, Ghana, Zimbabwe, Uganda and S. Africa. Background Paper for WDR.

[12]. Mosupye, F.M. and von holy, A. (1990).Microbiological quality and safety of ready-to-eat street- vended foods in Johannesburg, South Africa. Journal of Food Protection, Vol.62, pp1278-1284

[13]. Mukhola, M. S. (2007).Guidelines for an Environmental Education Training Programme for Street Food Vendors in Polokwane Cityhttp://etd.rau.ac.za/theses/submitted/etd-03132007- 140510/restricted/last.pdf, unpublished thesis, (Accessed 25 August 2011) 
[14]. Muzaffar, A. T, Huq, I, and Mallik, B. A. (2009).“Entrepreneurs of the Streets: An Analytical Work onthe Street Food Vendors of Dhaka City".International Journal of Business and Management,Vol.4, No.2, pp80-88

[15]. Pikuda, O.O., and Llelaboye, N.O.A. (2009). Proximate composition of street snacks purchased from $\quad$ selected motor parks in Lagos. Pakistan Journal of Nutrition, Vol.8, No.10, pp1657-1660

[16]. Ruel, M., Levin, C., Morris, S., Maxwell, D., Armar-Klemusu, M., and Ahiadeke, C. (1999). Workingwomen in an Urban Setting Traders, Vendors and Food Security in Accra. World Development1977-1991.

[17]. Saha, D. (2011).Working Life of Street Vendors in Mumbai. The Indian Journal of Labour Economics, $\quad$ Vol.54, No.2, pp301-326

[18]. Sardier, M., (2003). Women's Socio-Economic Roles in the Urban Sahel: a Preliminary Study of BamakoandNiamey. Journal of Political Ecology, Vol. 10,pp123-138

[19]. Sethuraman, S. V. 1981. The urban informal sector in developing countries: Employment, poverty andEnvironment. Geneva: International Labour Office.

[20]. Shivadekar, S. (2011). Food vendors must don gloves, maintain hygiene or pay 1L fine, TNN, August, 30,2011, http://articles.timesofindia.indiatimes.com/2011-08-30/mumbai/29944387 1 food- $\quad$ inspectors-food-vendors-unhygienicfood, (Accessed 31 August 2011)

[21]. Tinker, I. (1997).Street Foods: Urban Food and Employment in Developing Countries.New York: Oxford UniversityPress.

[22]. Verick, S. (2006). The Impact of Globalisation on the Informal Sector in Africa. Addis Ababa: UNECA.http://www.iza.org/conference files/worldb2006/verick s872.pdf (Accessed on 22 March 2012)

[23]. Winarno, F.G. and Allain, A. (1991). Street foods in developing countries: lessons from Asia. Rome: FAO.http://www.fao.org/docrep/U3550T/U3550T00.htm, (Accessed $24 \quad$ October 2011)

[24]. WHO (World Health Organisation) (2006). Street Food Vending in the Region: Food Safety Challenges. AFROFood Safety Newsletter Issue No.2, July 2006

[25]. ZIMSTAT (Zimbabwe National Statistics Agency) (2012). Census 2012 Preliminary Report. Harare: ZIMSTAT. 